\title{
Assessing Drinking Water Quality in Punjab, Pakistan
}

\section{Naeem Shahid ${ }^{1 *}$, Zahida Zia ${ }^{1}$, Muhammad Shahid', Hafiz Faiq Bakhat ${ }^{1}$, Seham Anwar², Ghulam Mustafa Shah', Muhammad Rizwan Ashraf ${ }^{1}$}

\author{
'Department of Environmental Sciences, COMSATS Institute of Information Technology, Vehari, Pakistan \\ ${ }^{2}$ College of Earth and Environmental Sciences, University of the Punjab, Lahore, Pakistan
}

\author{
Received: March 12, 2015 \\ Accepted: May 7, 2015
}

\begin{abstract}
Access to safe drinking water is crucial for healthy human life. Our study aimed to investigate the concentration of various pollutants in water samples collected from student hostels of the University of the Punjab in Lahore, Pakistan, and the potential risk of these pollutants for health. A total of 18 samples from 12 different locations were assessed for physical, biological, and chemical contaminants using standard methods. The concentrations of arsenic (As) and coliform bacteria were above the international standards given by the World Health Organization (WHO). The range of As concentration was from 24.92 to $32.72 \mu \mathrm{g} \cdot \mathrm{L}^{-1}$. Similarly, the two water samples showed bacterial contamination $38 \mathrm{MPN} / 100 \mathrm{~mL}$ and $21 \mathrm{MPN} / 100 \mathrm{~mL}$ - exceeding the standard value set by WHO $(0 \mathrm{MPN} / 100 \mathrm{~mL})$. We conclude that drinking water quality was poor, as is evident from the high concentration of As. Urgent measures are required to prevent such contamination and regular monitoring of drinking water quality in the study area.
\end{abstract}

Keywords: water quality, arsenic contamination, coliform bacteria, drinking water, health problems

\section{Introduction}

Supply of safe, clean, and abundant water for drinking purposes is essential for good health. According to a United Nations report [1], about 884 million people are not getting clean water. The availability of safe drinking water is a growing key concern for the international community. In the context of population boost and water contamination $[2,3]$, access to safe drinking water has become a global challenge in developing countries [4-7]. Water pollution has significant repercussions for the environment and human health [8]. It is also obvious that millions of people from poor countries die each year as a result of water-related preventable diseases $[9,10]$.

*e-mail: naeemshahid@ciitvehari.edu.pk naeembhatt1101@gmail.com
Different physical parameters such as $\mathrm{pH}, \mathrm{EC}$, and turbidity are important indicator of safe drinking water quality characteristics. Turbidity in water arises from the inclusion of silt, clay, and organic suspended particles. Turbidity of drinking water is related to its aesthetic as a qualitative parameter as it effects the visual acceptability of the water by the consumer. The $\mathrm{pH}$ of drinking water is a very important parameter that can have direct and indirect effects on quality. The $\mathrm{pH}$ of the water has a direct relationship with corrosiveness of the supply pipes and can increase the concentration of metals in the water. Direct exposure to water with extreme $\mathrm{pH}$ leads to irritation of the eyes, skin, and mucosal membranes [11].

Electrical conductivity and total dissolved solids are secondary water quality parameters and represent the activity or the total amount of cations and anions present in the water. The major cations and anions in drinking water are $\mathrm{Na}^{+}$, $\mathrm{Ca}^{+2}, \mathrm{Mg}^{+2}, \mathrm{~K}^{+}, \mathrm{CO}_{3}^{-2}, \mathrm{HCO}_{3}^{-}, \mathrm{Cl}^{-}$, and $\mathrm{SO}_{4}^{-2}$, and these should 
be present for good drinking water. However, these parameters may also represent some of the other ions toxic to humans such as As, nitrate, and fluoride. Although the major ions are essential nutrients for humans, beyond some limits these have a negative impact on human health. Higher concentrations of sulfates with $\mathrm{Na}$ and $\mathrm{Mg}$ impairs water taste and has a laxative effect. Similarly, higher concentrations of $\mathrm{Na}$ in drinking water may increase blood pressure in human populations. So physical parameters are just an indicator of drinking water quality and require chemical analysis for the distribution and contribution of the different actions and anions for recommendations about water quality.

Water contamination with toxic ions may result from natural and anthropogenic activities [12]. This may be the result of weathering of bedrock, industrialization, urbanization, and population growth [13]. Drinking water containing ions such as As, nitrates, and flouride may pose adverse effects to human health due to their toxicity [14]. Weathering of ore deposits is the most important geogenic source of metals/metalloid contribution to water contamination. The excessive intake of heavy metals/metalloid through water has a toxic effect on human health [8].

Arsenic is one of the major carcinogenic pollutants present in water resulting from both geogenic and anthropogenic sources [15]. Arsenic enters the food chain by polluting vegetables and food stuffs [16]. In nature As is present as organic methylated (monomethyl arsonic acid and dimethyl arsenic acid), inorganic (arsenate and arsenite), and gaseous arsine species. All the As species are toxic in nature [17], but inorganic species and arsine gas are more lethal as compared to the organic species [18]. Once absorbed, arsenate and arsenite replaces the psospahte ions and thiol group, respectively, in the biological systems, and impairs the normal functioning of the cells [19]. It may also bind to hemoglobin [20] and quickly be redistributed to the heart, kidneys, liver, lungs, nervous system, and other body organs. It undergoes hepatic biomethylation to form monomethyl arsenic and dimethyl arsenic acids that have less acute toxicity. A small amount of inorganic As is also excreted unchanged [21, 22].

Similarly, ingestion of nitrates through drinking water results in its reduction to nitrites that have the ability to bind with hemoglobin to form methemoglobin. Methemoglobin interferes with the $\mathrm{O}_{2}$-carrying capacity of blood. Unfortunately, small babies are more prone to methemoglobinemia (a higher conversion rate of nitrate to nitrite) [23]. Moreover, nitrite in the stomach due to acidic conditions is converted to N-nitroso compounds that have genotoxic potential in humans [24]. In addition, higher concentrations of fluoride in water samples in children result in impaired mental growth, plus skeletal and dental fluorosis [25]. The presence of total and fecal coliforms also indicates water contamination with animal and/or human wastes [26]. The worse biological contamination has been reported in several areas of Pakistan such as Islamabad and Rawalpindi [27], Khairpur [28], Lahore, Peshawar, and Karachi [29, 30]. Microbial contamination of drinking water is a major contributor to water-borne diseases like diarrhea, nausea, gastroenteritis, typhoid, dysentery, and other health-related problems $[28,31]$ - especially in children and persons with weak immune systems [31]. Microbial contamination of water in the country is one of the potential threats to public health and needs special attention to stop its further aggravation.

Like other developing countries, Pakistan is also facing serious public health issues as the result of water contamination with arsenic (As), a serious problem reported in different areas of Pakistan [32]. Rapid population growth and continuous industrial development has created immense stress on water capitals of the country. The prolonged droughts and increased population have further aggravated water scarcity and contamination. Although Pakistan has both ground and surface water resources, per capita water availability has decreased from $5,600 \mathrm{~m}^{3}$ to $1,000 \mathrm{~m}^{3}$ /annum [33]. Furthermore, the results of numerous investigations and surveys have indicated that water pollution has become a severe problem in Pakistan. The pollution levels are predominantly higher in and nearby the big cities of the country, where clusters of industries have been established [34]. High concentrations of arsenic have been reported in different areas of Pakistan, such as Lahore and Kasur [35], Jamshoro [15], the Muzaffargarh District [36], and Manchar lake [16, 37].

Keeping in mind the above-mentioned problems, the following study was conducted to determine the quality of drinking water in student hostels of the University of The Punjab, Lahore. The results of the present study give an overview of the severity of the availability and quality of drinking water used in big cities of Pakistan.

\section{Materials and Methods}

University student hostels lie in front of the Quaid-eAzam campus, University of the Punjab, Lahore, having a total of 10 hostels for women and 16 for men. The average number of population of the area is about 6,000 , including approximately 2,500 female and 3,500 male students. The rapid deterioration of drinking water quality of Lahore may cause serious health issues in local residents as well as university students. It was very important to assess the water quality in university hostels because of health concerns. Therefore, for the analysis of drinking water quality, six hostels for women were selected, which included three old and three new hostels. The old hostels are about 45 years old, while the new hostels were constructed about seven years ago.

The present source of water supply is based on independent deep wells. Tube wells are installed for meeting the water demand of the area until saturation. The consumptive uses of water include domestic use, lawn sprinkling, and firefighting. Storage reservoirs are an integral part of the water supply system. It is always essential to have some storage against breakdowns and to cater for the variations in demand. Overhead tanks serve two main storage purposes:

1. Equalizing and balancing, i.e., normal operations storage

2. Emergency and fire storage 
Water samples were collected from different locations of the hostel area. Basically there were two sampling locations. The source locations include six sampling points consisting of four tube wells and two overhead tanks. Water is supplied to all of the hostels from these source points. Therefore the water quality of these source points was very important, while consumer ends include six hostels consisting of two sampling points in each hostel that were tap and water coolers. These six consumer end points represented the water quality in university hostels. Collectively, there were 18 sampling points, including six sources and 12 hostel sampling points (Table 1).

Sampling was done at 24 April 2013 and 8 May 2013 under the guidance of a sampling team of the Pakistan Council for Research in Water Resources (PCRWR). The standard method of sampling and examination of water given by the American Public Health Association was followed [38]. Sterilized plastic bottles with volume of $500 \mathrm{~mL}$ were used for sample collection. Before collection of samples, taps were sterilized with the help of spirit-dipped cotton rod flame. Afterward, the tap was opened for one minute to maintain medium flow of water, and then bottles were filled with sample water and closed tightly with the help of adhesive taps. For bacterial testing, samples were used the very same day and for chemical testing samples were preserved at $4^{\circ} \mathrm{C}$ using the reagents. Samples were categorized into four classes on the basis of analysis type and preservation method.

Type A: Microbiological analysis

Type B: $\quad 2-10 \mathrm{~mL} \mathrm{HNO}_{3}$ as preservative for trace elements

Type C: $1 \mathrm{~mL} / 100 \mathrm{~mL} 1 \mathrm{M}$ boric acid as preservative for nitrate-N

Type D: No preservative for other water quality parameters

Water samples were analyzed to determine characteristics such as $\mathrm{pH}$, electrical conductivity, alkalinity, hardness, TDS, turbidity, carbonates, bicarbonates, chloride, fluoride, sulphates, nitrates, sodium, potassium, calcium, magnesium, iron, arsenic, total coliform, and E. coli. There were four different sets of samples according to their collection site (tube wells, overhead tanks, taps and water coolers), so they were analyzed for different parameters according to standard methods.

Source samples, which include the tube wells and overhead tanks, were analyzed for all chemical and microbial parameters, while tap-water samples were analyzed for all chemical and bacterial parameters but not analyzed for arsenic and fluoride. The water from coolers was tested to measure $\mathrm{pH}$, turbidity, and microbial contamination. Color, odor, and taste were measured using senses, while other remaining analyses were carried out in a PCRWR laboratory. Results of all these parameters were compared with standards given by WHO (World Health Organization) [39], the U.S. EPA [40], and the National Standards for Drinking Water Quality (NSDWQ) of Pakistan [41].

To find out the health risks in the study area, random interviews were carried out to get information about drinking water sources, body weight, age, smoking habits,
Table 1. Sampling point names and their codes.

\begin{tabular}{|c|c|c|}
\hline No. & Sampling point name & Sampling point code \\
\hline & \multicolumn{2}{|l|}{ Source points } \\
\hline 1. & Girls Hostel 1 Tube Well & G1-TW \\
\hline 2. & Boys Hostel 1 Tube Well & B1-TW \\
\hline 3. & Boys Hostel 18 Tube Well & B18-TW \\
\hline 4. & Girls Hostel 8 Tube Well & G8-TW \\
\hline 5. & Girls Hostel 1 Overhead Tank & G1-OHT \\
\hline \multirow[t]{2}{*}{6.} & Boys Hostel 1 Overhead Tank & B1-OHT \\
\hline & \multicolumn{2}{|c|}{ Consumer points } \\
\hline 1. & $\begin{array}{c}\text { Girls Hostel } 1 \text { Tap } \\
\text { (Hazrat Khadija R.A Hall) }\end{array}$ & G1-T \\
\hline 2. & Girls Hostel 1 Water Cooler & G1-C \\
\hline 3. & $\begin{array}{c}\text { Girls Hostel } 2 \text { Tap } \\
\text { (Hazrat Ayesha Siddeqa R.A Hall) }\end{array}$ & G2-T \\
\hline 4. & Girls Hostel 2 Water Cooler & $\mathrm{G} 2-\mathrm{C}$ \\
\hline 5. & $\begin{array}{c}\text { Girls Hostel } 3 \text { Tap } \\
\text { (Hazrat Mariam R.A Hall) }\end{array}$ & G3-T \\
\hline 6. & Girls Hostel 3 Water Cooler & G3-C \\
\hline 7. & $\begin{array}{c}\text { Girls Hostel } 7 \text { Tap } \\
\text { (Hazrat Asma R.A Hall) }\end{array}$ & G7-T \\
\hline 8. & Girls Hostel 7 Water Cooler & G7-C \\
\hline 9. & $\begin{array}{c}\text { Girls Hostel } 8 \text { Tap } \\
\text { (Hazrat Hafsa R.A Hall) }\end{array}$ & G8-T \\
\hline 10. & Girls Hostel 8 Water Cooler & G8-C \\
\hline 11. & $\begin{array}{c}\text { Girls Hostel } 9 \text { Tap } \\
\text { (Hazrat Sakina R.A Hall) }\end{array}$ & G9-T \\
\hline 12. & Girls Hostel 9 Water Cooler & G9-C \\
\hline
\end{tabular}

income, and other health issues. During the interview session, it was observed that students use ground and surface water, as well as bottled mineral water for drinking purposes. Further assessment was carried out by calculating the chronic daily intake (CDIs) and health risk indexes (HRIs) for drinking water for PU hostel residents.

Toxic heavy metals enter the human body through many different pathways, including oral intake (by consuming food), dermal contact, and inhalation. Oral intake (water) is considered the major method of metal entry [42], therefore the chronic intake and health risk index of arsenic was determined using the equation given below [43]:

$$
C D I=\frac{M_{c} \times L_{\mathrm{w}}}{W_{b}}
$$

...where $M_{c}\left(\mu g \mathrm{~L}^{-1}\right)$ is the concentration of metal in water while $L_{w}$ (L/day) is daily water intake that is considered as $1 \mathrm{~L} /$ day for child and $2 \mathrm{~L} /$ day for an adult [44], and $W_{b}(\mathrm{~kg})$ is body weight that is assumed as $32.7 \mathrm{~kg}$ and $72 \mathrm{~kg}$ for child and adult, respectively $[8,14,45]$. 
Table 2. Physico-chemical parameters.

\begin{tabular}{|c|c|c|c|c|c|c|c|}
\hline No & Iocation code & $\mathrm{nH}$ & $\mathrm{EC}$ & Turbidity & Alkalinity & TDS & Hardness \\
\hline & & & $\mu \mathrm{S} \cdot \mathrm{cm}^{-1}$ & NTU & \multicolumn{3}{|c|}{$\mathrm{mg} \cdot \mathrm{L}^{-1}$} \\
\hline 1. & GH1-TW & 7.78 & 436 & BDL & 4.2 & 279 & 42 \\
\hline 2. & BH1-TW & 7.75 & 474 & 0.30 & 4.4 & 297 & 60 \\
\hline 3. & BH18-TW & 7.87 & 426 & 0.10 & 3.8 & 259 & 35 \\
\hline 4. & GH8-TW & 7.77 & 470 & BDL & 4.2 & 270 & \\
\hline 5. & GH1-OHT & 7.71 & 474 & $\mathrm{BDL}$ & 4.4 & 298 & 57 \\
\hline 6. & BH1-OHT & 7.76 & 471 & 0.30 & 4.4 & 289 & 60 \\
\hline 7. & GH1-T & 7.78 & 434 & BDL & 4 & 258 & 40 \\
\hline 8. & GH1-C & 7.72 & - & BDL & - & - & - \\
\hline 9. & GH2-T & 7.83 & 430 & 0.10 & 4 & 430 & 40 \\
\hline 10. & $\mathrm{GH} 2-\mathrm{C}$ & 7.95 & - & 1.30 & - & - & - \\
\hline 11. & GH3-T & 7.79 & 452 & BDL & 4 & 276 & 45 \\
\hline 12. & GH3-C & 7.73 & - & 0.30 & - & - & - \\
\hline 13. & GH7-T & 7.81 & 436 & BDL & 4 & 274 & 45 \\
\hline 14. & GH7-C & 7.84 & - & 0.80 & - & - & - \\
\hline 15. & GH8-T & 7.82 & 415 & 0.20 & 3.8 & 266 & 40 \\
\hline 16. & GH8-C & 7.78 & - & BDL & - & - & - \\
\hline 17. & GH9-T & 7.96 & 428 & BDL & 4 & 273 & 35 \\
\hline 18. & GH9-C & 7.92 & - & BDL & - & - & - \\
\hline
\end{tabular}

$\mathrm{BDL}$ - below detection limit

To find out the chronic health problems, the health risk index was calculated by using a modified form of equation as used by Khan et al. [43]:

$$
H R I=\frac{C D I}{R f D} \times 0.001
$$

...where $H R I$ is health risk index, $C D I$ is chronic daily intake, $R f D$ is the reference dose for oral toxicity of As that is $0.0003 \mathrm{mg} \cdot \mathrm{kg}^{-1} \cdot \mathrm{day}^{-1}$ [46], and 0.001 is the conversion factor for downscaling the reference dose $(R f D)$ from $\mathrm{mg}$ to $\mu \mathrm{g} . H R I<1$ will be the limit for safe mode of water consumption.

\section{Results}

Characteristics of physico-chemical parameters (alkalinity, turbidity, pH, EC, TDS, and hardness) of studied water samples are summarized in Table 2, which indicates that all the parameters were under permissible levels. Likewise, alkalinity values ranged from 3.8 to $4.4 \mathrm{mg} \cdot \mathrm{L}^{-1}$. There are no set values for alkalinity by WHO, NSDWQ (National Standards for Drinking Water Quality), and the U.S. EPA. Similarly, the turbidity level of water samples was below the permissible limit ( 5 NTU) given by WHO and NSDWQ, as recorded values were in the range of BDL to 1.3 NTU. The $\mathrm{pH}$ values ranged from $7-8$ but did not deviate from the standard limit (6.5 to 8.5$)$ provided by WHO and NSDWQ. The $\mathrm{pH}$ at sample source location was slightly higher (7.72-7.96) than that of the place of consumption or end user (7.71-7.87).

Electrical conductivity (EC) was measured for all samples of water sources and tap-water samples of consumer ends. The range of EC was recorded as $415 \mu \mathrm{S} / \mathrm{cm}-474$ $\mu \mathrm{S} / \mathrm{cm}$. There are no international standards for EC in WHO guidelines, NSDWQ, and the U.S. EPA. Similarly, TDS and hardness of analyzed samples ranged from 258 to $430 \mathrm{mg} \cdot \mathrm{L}^{-1}$ and 35 to $60 \mathrm{mg} \cdot \mathrm{L}^{-1}$, respectively. Both TDS and hardness were below the permissible levels given by WHO guidelines and NSDWQ, which are $1,000 \mathrm{mg} \cdot \mathrm{L}^{-1}$ (for TDS) and $500 \mathrm{mg} \cdot \mathrm{L}^{-1}$ (for hardness).

Table 3 summarizes the levels of $\mathrm{Ca}, \mathrm{Mg}, \mathrm{Na}, \mathrm{K}, \mathrm{Fe}$, and As in samples collected from the designated study area. The presence of higher levels of calcium in drinking water can lower cardiovascular disease mortality. Mineral deposits are formed by ionic reactions resulting in the formation of insoluble precipitates. In this study the concentration of $\mathrm{Ca}$ in water samples ranged from 8 to $14 \mathrm{mg} \cdot \mathrm{L}^{-1}$. There are no standard values regarding calcium in WHO, NSDWQ, and the U.S. EPA. The Kingdom of Saudi Arabia (KSA) recommended the water quality standards for calcium as 75 $\mathrm{mg} \cdot \mathrm{L}^{-1}$. Therefore, all the Ca values are below the given KSA standards. Magnesium $(\mathrm{Mg})$ and sodium $(\mathrm{Na})$ values 
Table 3. Cation concentrations in water samples.

\begin{tabular}{|c|c|c|c|c|c|c|}
\hline \multirow[t]{2}{*}{ No. } & \multirow[t]{2}{*}{$\begin{array}{l}\text { Location } \\
\text { code }\end{array}$} & $\frac{\Xi}{\stackrel{\Xi}{\Xi}}$ & 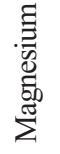 & 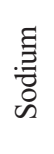 & 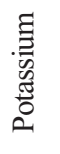 & రี \\
\hline & & \multicolumn{5}{|c|}{$\mathrm{mg} \cdot \mathrm{L}^{-1}$} \\
\hline 1. & GH1-TW & 10 & 4.9 & 93 & 1.4 & 0.08 \\
\hline 2. & BH1-TW & 12 & 7.3 & 93 & 1.5 & 0.07 \\
\hline 3. & BH18-TW & 8 & 3.6 & 90 & 1.1 & 0.06 \\
\hline 4. & GH8-TW & 12 & 4.1 & 92 & 1.4 & 0.07 \\
\hline 5. & GH1-OHT & 14 & 5.5 & 95 & 1.6 & 0.06 \\
\hline 6. & BH1-OHT & 12 & 7.3 & 89 & 1.4 & 0.07 \\
\hline 7. & GH1-T & 8 & 4.9 & 84 & 1.2 & 0.08 \\
\hline 8. & GH1-C & - & - & - & - & - \\
\hline 9. & GH2-T & 10 & 3.6 & 87 & 1.3 & 0.09 \\
\hline 10. & $\mathrm{GH} 2-\mathrm{C}$ & - & - & - & - & - \\
\hline 11. & GH3-T & 10 & 4.9 & 93 & 1.5 & 0.08 \\
\hline 12. & GH3-C & - & - & - & - & - \\
\hline 13. & GH7-T & 10 & 4.9 & 90 & 1.3 & 0.06 \\
\hline 14. & GH7-C & - & - & - & - & - \\
\hline 15. & GH8-T & 10 & 3.6 & 91 & 1.2 & 0.08 \\
\hline 16. & GH8-C & - & - & - & - & - \\
\hline 17. & GH9-T & 8 & 3.6 & 93 & 1.2 & 0.06 \\
\hline 18. & GH9-C & - & - & - & - & - \\
\hline
\end{tabular}

were also below the standards $\left(\mathrm{Mg}: 150 \mathrm{mg} \cdot \mathrm{L}^{-1}, \mathrm{Na}: 200\right.$ $\mathrm{mg} \cdot \mathrm{L}^{-1}$ ), ranging from 3.6 to $7.3 \mathrm{mg} \cdot \mathrm{L}^{-1}$ and $84 \mathrm{mg}$ to 95 $\mathrm{mg} \cdot \mathrm{L}^{-1}$, respectively. Similarly, recorded concentrations of $\mathrm{K}$ and $\mathrm{Fe}$ ranged from 01.1 to $1.6 \mathrm{mg} \cdot \mathrm{L}^{-1}$ and 0.06 to 0.09 $\mathrm{mg} \cdot \mathrm{L}^{-1}$, respectively. There is not any standard for $\mathrm{K}$ and $\mathrm{Fe}$ concentrations for drinking water, but a secondary standard for $\mathrm{Fe}$ in WHO guidelines is provided as $0.3 \mathrm{mg} \cdot \mathrm{L}^{-1}$. Therefore, all the Fe values were below this secondary standard.

In this study, the concentration of carbonates was below the detection level while bicarbonates with high concentrations ranged from 190 to $220 \mathrm{mg} \cdot \mathrm{L}^{-1}$ (Table 4). A high concentration of bicarbonates is not good as it combines with major cations to produce their salts in water. The study area showed the same type of water group $\mathrm{Na}-\mathrm{K}-\mathrm{HCO}_{3}$ when it was plotted on Piper diagram (Fig. 1). Standard values are not given for concentrations of carbonates and bicarbonates in water. Moreover, insignificant variation in the results of samples taken from the source and the consumer end indicates the quality of water remained the same during its passage from the source to the consumer end. Similarly, the concentrations of sulphates and nitrates were analyzed in water samples that ranged from 28 to $37 \mathrm{mg} \cdot \mathrm{L}^{-1}$ and $\mathrm{BDL}$ to
Table 4. Concentrations of anions in water samples.

\begin{tabular}{|c|c|c|c|c|c|c|c|}
\hline No. & $\begin{array}{l}\text { Location } \\
\text { code }\end{array}$ & 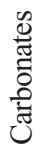 & 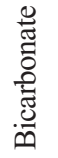 & $\frac{\frac{\pi}{0}}{\frac{0}{0}}$ & $\underset{\stackrel{\Xi}{\Xi}}{\stackrel{\Xi}{E}}$ & $\frac{\stackrel{\Xi}{\mathbb{E}}}{\stackrel{\Xi}{\Xi}}$ & 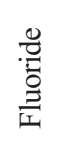 \\
\hline & & \multicolumn{6}{|c|}{$\mathrm{mg} \cdot \mathrm{L}^{-1}$} \\
\hline 1. & GH1-TW & Nil & 210 & 10 & 0.039 & 34 & 0.31 \\
\hline 2. & BH1-TW & Nil & 210 & 14 & 0.035 & 37 & 0.27 \\
\hline 3. & BH18-TW & Nil & 190 & 10 & 0.053 & 32 & 0.28 \\
\hline 4. & GH8-TW & Nil & 210 & 14 & 0.034 & 35 & 0.30 \\
\hline 5. & GH1-OHT & Nil & 220 & 14 & BDL & 36 & 0.25 \\
\hline 6. & BH1-OHT & Nil & 220 & 10 & 0.025 & 37 & 0.32 \\
\hline 7. & GH1-T & Nil & 200 & 14 & 0.053 & 28 & - \\
\hline 8. & GH1-C & - & - & - & - & - & - \\
\hline 9. & GH2-T & Nil & 200 & 10 & 0.066 & 30 & - \\
\hline 10. & $\mathrm{GH} 2-\mathrm{C}$ & - & - & - & - & - & - \\
\hline 11. & GH3-T & Nil & 200 & 14 & 0.074 & 32 & - \\
\hline 12. & GH3-C & - & - & - & - & - & - \\
\hline 13. & GH7-T & Nil & 200 & 12 & 0.075 & 36 & - \\
\hline 14. & GH7-C & - & - & - & - & - & - \\
\hline 15. & GH8-T & Nil & 190 & 12 & 0.059 & 34 & - \\
\hline 16. & GH8-C & - & - & - & - & - & - \\
\hline 17. & GH9-T & Nil & 200 & 12 & 0.074 & 35 & - \\
\hline 18. & GH9-C & - & - & - & - & - & - \\
\hline
\end{tabular}

Nil - not detectable

$0.025 \mathrm{mg} \cdot \mathrm{L}^{-1}$, respectively, and were below the standard level (sulphates: $250 \mathrm{mg} \cdot \mathrm{L}^{-1}$, nitrates: $\mathrm{mg} \cdot \mathrm{L}^{-1}$ ). The concentration of fluoride was determined only in source water samples, but chloride was also measured in tap water. Their concentrations ranged from 0.25 to $0.32 \mathrm{mg} \cdot \mathrm{L}^{-1}$ and 10 to $14 \mathrm{mg} \cdot \mathrm{L}^{-1}$, respectively, which is below the permissible levels described by WHO, NSDWQ, and the U.S. EPA.

The total and fecal coliform values in water samples are given in Table 5. Only samples taken from GH1-T and GH9-T showed total coliform contamination that is $38 \mathrm{MPN} / 100 \mathrm{~mL}$ and $21 \mathrm{MPN} / 100 \mathrm{~mL}$, respectively, while the fecal coliforms were not detected in all samples taken from source and user end points. Therefore, only two samples exceeded the permissible values set by WHO, NSDWQ, and the U.S. EPA (0 MPN/100 mL).

The value of arsenic (As) was measured only for the source water samples, including four tube wells and two overhead tanks (Table 6). The range of As concentrations was from 24.92 to $32.72 \mu \mathrm{g} \cdot \mathrm{L}^{-1}$. The maximum value was showed by a water sample taken from BH1-TW while the lowest was from BH18-TW. The concentrations of As in all analyzed samples were higher than the permissible limits given by WHO $\left(0.01 \mathrm{mg} \cdot \mathrm{L}^{-1}\right)$ and NSDWQ $\left(0.050 \mathrm{mg} \cdot \mathrm{L}^{-1}\right)$. 
Table 5. Biological contaminants $(0 / 100 \mathrm{ml}$ of sample $)$.

\begin{tabular}{|c|c|c|c|}
\hline No. & $\begin{array}{c}\text { Location } \\
\text { code }\end{array}$ & $\begin{array}{c}\text { Total coliforms } \\
0 / 100 \mathrm{~mL}^{-1} \\
\text { of sample }\end{array}$ & $\begin{array}{c}\text { Fecal coliforms } \\
0100 \mathrm{~mL}^{-1} \\
\text { of sample }\end{array}$ \\
\hline 1. & GH1-TW & 0 & 0 \\
\hline 2. & BH1-TW & 0 & 0 \\
\hline 3. & BH18-TW & 0 & 0 \\
\hline 4. & GH8-TW & 0 & 0 \\
\hline 5. & GH1-OHT & 0 & 0 \\
\hline 6. & BH1-OHT & 0 & 0 \\
\hline 7. & GH1-T & 38 & 0 \\
\hline 8. & GH1-C & 0 & 0 \\
\hline 9. & GH2-T & 0 & 0 \\
\hline 10. & GH2-C & 0 & 0 \\
\hline 11. & GH3-T & 0 & 0 \\
\hline 12. & GH3-C & 0 & 0 \\
\hline 13. & GH7-T & 0 & 0 \\
\hline 14. & GH7-C & 0 & 0 \\
\hline 15. & GH8-T & 0 & 0 \\
\hline 16. & GH8-C & 0 & 0 \\
\hline 17. & GH9-T & 21 & 0 \\
\hline 18. & GH9-C & 0 & 0 \\
\hline
\end{tabular}

Results for the assessment of CID and HRI from As in drinking water are presented in Table 6, which shows that CID and HRI values were very high in water. Chronic daily intake (CDI) of water for children and adults ranged from 0.762 to 1.001 and 0.692 to 0.909 , respectively. The HRI values ranged from 2.54 to 3.33 and 2.307 to 3.03 for children and adults, respectively.

\section{Discussion}

The groundwater source has been used for drinking, cooking, washing, and other domestic purposes in understudy areas of the PU, Lahore, Pakistan. Drinking water is a source of metals such as $\mathrm{Cu}, \mathrm{Fe}, \mathrm{Co}, \mathrm{Zn}$, and $\mathrm{Mg}$, which are essential for human health. But in exessive or deficient amounts they can disrupt the body systems and cause illness. Some of the metals may not be required and are hazardous in nature, such as $\mathrm{Cd}, \mathrm{Pb}, \mathrm{Cr}$, and $\mathrm{As}$. Exeeding permissible levels, they become toxic to humans and cause biological and mental disoders. Arsenic is one of the major toxic carcinogens in drinking water. Our study revealed high levels of As in ground water samples (Table 6).

$\mathrm{pH}$ is an imperative parameter for water quality testing and helpful for water chemistry interpretation. The $\mathrm{pH}$ of water samples from the study area were slightly alkaline ( $\mathrm{pH}$ 7.71-7.96), but within the WHO recommended values and less than those reported by Muhammad et al. [47] and Halim et al. [48]. The values for alkalinity $\left(3.8-4.4 \mathrm{mg} \cdot \mathrm{L}^{-1}\right)$, turbidity (0.1-1.3 NTU), EC (415-474 $\mu \mathrm{S} / \mathrm{cm})$, TDS (258$\left.430 \mathrm{mg} \cdot \mathrm{L}^{-1}\right)$, and hardness $\left(35-60 \mathrm{mg} \cdot \mathrm{L}^{-1}\right)$ were found with-

\section{Piper Diagram}

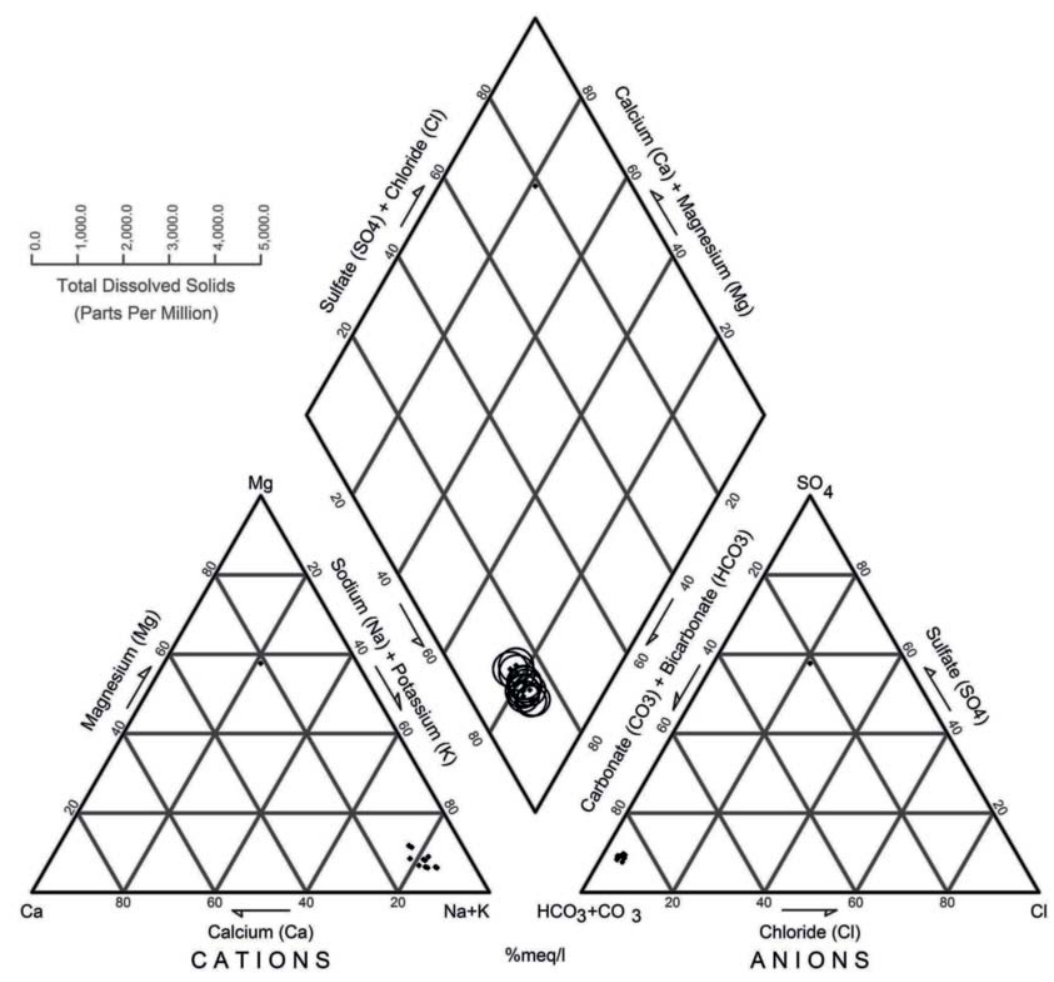

Fig. 1. Piper diagram showing type of water. 
Table 6. As levels, CDIs $\left(\mu \mathrm{g} \cdot \mathrm{kg}^{-1} \cdot \mathrm{day}^{-1}\right)$, and HRIs for individuals.

\begin{tabular}{|c|c|c|c|c|c|}
\hline \multirow{2}{*}{ Site code } & Arsenic & \multicolumn{2}{|c|}{ CDIs $\left(\mu \mathrm{g} \cdot \mathrm{kg}^{-1} \cdot \mathrm{day}^{-1}\right)$} & \multicolumn{2}{l|}{ Health risk indexes } \\
\cline { 2 - 6 } & $\mu \mathrm{g} \cdot \mathrm{L}^{-1}$ & Children & Adults & Children & Adults \\
\hline GH1-TW & 25.40 & 0.777 & 0.706 & 2.589 & 2.352 \\
\hline BH1-TW & 32.72 & 1.001 & 0.909 & 3.335 & 3.030 \\
\hline BH18-TW & 24.92 & 0.762 & 0.692 & 2.540 & 2.307 \\
\hline GH8-TW & 25.33 & 0.775 & 0.704 & 2.582 & 2.345 \\
\hline GH1-OHT & 26.82 & 0.820 & 0.745 & 2.734 & 2.483 \\
\hline BH1-OHT & 25.65 & 0.784 & 0.713 & 2.615 & 2.375 \\
\hline
\end{tabular}

in the permissible limits described by WHO. The TDS and EC values of water samples in the current study were below those reported by Baig et al. [15]. The concentrations of calcium $\left(8-14 \mathrm{mg} \cdot \mathrm{L}^{-1}\right)$, magnesium $\left(3.6-7.3 \mathrm{mg} \cdot \mathrm{L}^{-1}\right)$, sodium (84-95 $\left.\mathrm{mg} \cdot \mathrm{L}^{-1}\right)$, potssium $\left(1.1-1.6 \mathrm{mg} \cdot \mathrm{L}^{-1}\right)$, and iron $(0.06-$ $\left.0.09 \mathrm{mg} \cdot \mathrm{L}^{-1}\right)$ were within the given standards. Furthermore, the concentrations of anions such as carbonates (BDL), bicarbonates $\left(190-220 \mathrm{mg} \cdot \mathrm{L}^{-1}\right)$, chloride $\left(10-14 \mathrm{mg} \cdot \mathrm{L}^{-1}\right)$, fluoride $\left(0.25-0.32 \mathrm{mg} \cdot \mathrm{L}^{-1}\right)$, niterates $\left(0.025-0.075 \mathrm{mg} \cdot \mathrm{L}^{-1}\right)$, and sulphates $\left(28-37 \mathrm{mg} \cdot \mathrm{L}^{-1}\right)$ were below the recommended standard values. In a current study the concentrations of calcium, sodium, carbonates, bicarbonates, chloride, fluoride, nitrates, and sulphates were less than those reported by Farooqi et al. [35] in the Lahore and Kasur regions (calcium: 8.4 to $44.8 \mathrm{mg} \cdot \mathrm{L}^{-1}$, sodium: $301-878 \mathrm{mg} \cdot \mathrm{L}^{-1}$, bicarbonates: $579-1,900 \mathrm{mg} \cdot \mathrm{L}^{-1}$, chloride: 20.4 to $299 \mathrm{mg} \cdot \mathrm{L}^{-1}$, fluoride: $2.47-21.1 \mathrm{mg} \cdot \mathrm{L}^{-1}$, nitrates: up to $64 \mathrm{mg} \cdot \mathrm{L}^{-1}$, and sulphates: $\left.110-1,550 \mathrm{mg} \cdot \mathrm{L}^{-1}\right)$.

Results of our study showed high concentratons of As in water samples $\left(24.92-32.72 \mu \mathrm{g} \cdot \mathrm{L}^{-1}\right)$. All these values were higher than the permissible level described by WHO $\left(10 \mu \mathrm{g} \cdot \mathrm{L}^{-1}\right)$. In the current study, As concentrations in water samples were higher than those reported by Muhammad et al. [47], but lower than those reported by Farooqi et al. [35] in the Lahore and Kasur districts rain and groundwater $\left(<10.00-1,900.00 \mathrm{lg} \cdot \mathrm{L}^{-1}\right)$, Nickson et al. [36] in the Muzaffargarh District surface and groundwater (1.00$\left.905.00 \mathrm{lg} \cdot \mathrm{L}^{-1}\right)$, Baig et al. [15] in Jamshoro surface and groundwater (3.00-106.00 $\left.\mathrm{lg} \cdot \mathrm{L}^{-1}\right)$, and Arain et al. [16] in Mancher Lake water (35.00-157.00 $\left.\mathrm{gg} \cdot \mathrm{L}^{-1}\right)$ and adjoining groundwater $\left(23.30-96.30 \mathrm{lg} \cdot \mathrm{L}^{-1}\right)$.

Determining the As level in drinking water, CDIs and HRIs were also calculated to estimate the health risk due to its high concentration. Water is an essential need for the human body. Therefore a considerable amount of As can be absorbed by individuals. The values for CID ranged from $0.762-1.001 \mu \mathrm{g} \cdot \mathrm{kg}^{-1} \cdot \mathrm{day}^{-1}$ in children and 0.692-0.909 $\mu \mathrm{g} \cdot \mathrm{kg}^{-1} \cdot \mathrm{day}^{-1}$ in adults. The HRI values were high, ranging from 2.54-3.335 for children and 2.307-3.03 for adults. All HRI values were higher than those reported by Muhammad et al. [47]. The higher HRI values (HRI $>1$ ) highlight a probable human health risk for the future via water intake. Arsenic is a non-essential element for growth and causes several biological disorders even at very low concentrations. Results of this study showed that the use of As-contaminated water for drinking purposes might cause different kinds of cancers as well as neurological problems [49]. Prolonged exposure to arsenic-contaminated water enhances the risk of lungs, kidney, liver, and bladder cancer in human beings $[50,51]$. In addition, it also causes several noncancerous diseases such as hypertension, liver disorders, peripheral vascular diseases, diabetes mellitus, and neurological and respiratory problems [52]. The earliest effects of As ingestion through drinking water include hyperkeratosis and pigmentation changes that appear after 5-10 years exposure [53, 54], and cause malignant as well as nonmalignant health issues ultimately. Keratosis and hyperpigmentation are types of skin lesions caused by Ascontaminated drinking water [55]. Even in high concentrations, it may lead to death. Arsenic exposure leads to diseases and causes death, which can ultimately have an adverse effect on the GDP of the country through human resource losses as well as an extra burden on the health system of the country. In Bangladesh, one of each 16 adult deaths is due to As exposure and, as a result, GDP is reduced by premature deaths [56]. Consequently, the drinking water in PU hostels has the potential to pose detrimental effects on human health regarding As content.

There are several natural ways for As enrichment in ground water [57], including oxidation of minerals containing arsenic sulphide [58], and the reduction of $\mathrm{FeOOH}$, which releases sorbed As load to groundwater [59, 60]. Desorption processes are triggered due to increases in $\mathrm{pH}$ level [61]. The source of arsenic may be the erosion of natural deposits, runoff from orchards, and runoff from industrial and municipal wastes. Anthropogenic activities also intensified the As contamination in water by several means such as processing and combustion of fossil fuels, production and use of arsenical pesticides in agriculture, and incineration and disposal of industrial and municipal wastes $[62,63]$. From these sources, As releases to the soil - especially in the form of pesticides and solid waste, from which its soluble forms ultimately leach out to the ground water [64]. In this study, As enrichment may be due to the leaching of lake water containing a heavy load of pollution. Other sources of As contamination may be its desorption from sorption sites due to slightly high $\mathrm{pH}$ levels.

In addition to arsenic, biological contamination was also observed in this study. Two sampling points, i.e. GH1$\mathrm{T}$ and GH9-T, showed total coliform contamination of 38 MPN/100 mL and $21 \mathrm{MPN} / 100 \mathrm{~mL}$, respectively. These values are higher than the standard limits set by WHO, NSDWQ, and the U.S. EPA (0 MPN/100 mL). But samples taken from water coolers of these sites showed zero bacterial contamination, which confirms the working efficiency of water filtration units. The concentration of coliform bacteria detected in the current study was lower than those reported by Ahmad et al. [65] in Akram Park, Chota Sandha Stop (50 MPN/100 mL), Khalid Shah Filling Station, PSO pump, Qasurpura GT road (93 MPN/100 mL), Mahmood Booti, Arif Steel Mills, Wahga Town (39 MPN/100 mL), and G Block of Johar Town (90 MPN/100 mL). 
In our study, contamination on these two points (GH1$\mathrm{T}$ and GH9-T) was maybe due to old water distribution pipes. Coliform bacteria have been reported by different authors in old corroded pipes [66, 67]. According to Emde et al. [68] corrosion deposits show a greater number of total coliforms than untreated water supply. Discharge from septic tanks and sewage systems may also contaminate drinking water supply systems. Coliform bacteria may not cause disease, but they are used as one of the indicators of pathogenic contamination that can cause different diseases, e.g. dysentery, intestinal infections, typhoid fever, hepatitis, cholera, and other illnesses [68].

\section{Conclusions}

In this study, samples were taken from two types of sources. One was the Tube Wells, which provided water for the consumers through a piping system and overhead tanks. All these sources were contaminated with As, as its value was exceeding the permissible standard limits $\left(10 \mu \mathrm{g} \cdot \mathrm{L}^{-1}\right)$ provided by WHO. As is considered one of the most dangerous trace elements, so the quality of source water was poor. Other than As, all the parameters were under permissible levels. On the other hand, water samples taken from the end-user point showed bacterial contamination in tap water samples (GH1-T:38 MPN/100 mL, GH9-T:21 MPN/100 mL), while samples taken from coolers of GH1 and GH9 showed $0 \mathrm{MPN} / 100 \mathrm{~mL}$, which assures the working efficiency of filters installed for drinking water.

\section{Recommendations}

As the source water has As contamination, the water should be monitored extensively to find the actual cause of contamination. Measures for the prevention of this contamination should be taken. Because As is a dangerous substance, it has serious health concerns, and As contamination will continue due to geogenic activities. For that reason, authors suggest that the consumption of contaminated drinking water should be stopped. Different As treatment technologies should be adopted for safe drinking water. Similarly, microbial contamination was detected in two samples, which is a serious threat to human health. So this problem should be considered seriously. Government and administration of the University of the Punjab should take measures to provide safe drinking water.

\section{Acknowledgements}

We acknowledge all the people who have contributed to the completion of this research, especially the sampling team of the Pakistan Council for Research in Water Resources (PCRWR) for providing help in sampling and analysis.

\section{References}

1. WHO/UNICEF. Joint Monitoring Programme on Water Supply and Sanitation, "Progress in Sanitation and Drinking Water: 2010 Update," WHO and UNICEF, Geneva. 2010.

2. LAMBOOY T. Corporate social responsibility: sustainable water use. J. Clean. Prod. 19, (8), 852, 2011.

3. DOMĖNECH L., SAURÍ D. A comparative appraisal of the use of rainwater harvesting in single and multi-family buildings of the Metropolitan Area of Barcelona (Spain): social experience, drinking water savings and economic costs. J. Clean. Prod. 19, (6), 598, 2011.

4. MONTGOMERY M. A., ELIMELECH M. Water and sanitation in developing countries: including health in the equation. Environ. Sci. Technol. 41, (1), 17, 2007.

5. COHEN B. Urbanization in developing countries: Current trends, future projections, and key challenges for sustainability. Technol. Soc. 28, (1), 63, 2006.

6. CHAN C. L., ZALIFAH M. K., NORRAKIAH A. S. Microbiological and physiochemical quality of drinking water. Malaysian. J. Analyt. Sci. 11, 414, 2007.

7. ABDEL-MOETY N. M., AL-FASSI F. A., ALI M. A. Health aspects of virological water quality: an overview review. J. Appl. Sci. Res. 4, 1205, 2008.

8. MUHAMMAD S., SHAH M. T., KHAN S. Health risk assessment of heavy metals and their source apportionment in drinking water of Kohistan region, northern Pakistan. Microchem. J. 98, (2), 334, 2011.

9. WHO. Burden of food borne diseases, Geneva. 2007.

10. TUMWINE J. K., THOMPSON J., KATUA-KATUA M., MUJWAJUZI M., JOHNSTONE N., WOOD E., PORRAS I. Diarrhoea and effects of different water sources, sanitation and hygiene behaviour in East Africa. Trop. Med. Int. Health. 7, (9), 750, 2002.

11. WHO. Health Impact of Acidic Deposition. Sci. Total Environ. 52, 157, 1986.

12. RAPANT S., KRCMOVA K. Health risk assessment maps for arsenic groundwater content, application of national geochemical databases. Environ. Geochem. Health. 29, (2), 131, 2007.

13. VELEA T., GHERGHE L., PREDICA V., KREBS R. Heavy metal contamination in the vicinity of an industrial area near Bucharest. Environ. Sci. Pollut. R. 16, (1), 27, 2009.

14. KHAN S., REHMAN S., KHAN A. Z., KHAN M. A., SHAH M. T. Soil and vegetables enrichment with heavy metals from geolog-ical sources in Gilgit, northern Pakistan. Ecotox. Environ. Safe. 73, (7), 1820, 2010.

15. BAIG J. A., KAZI T. G., ARAIN M. B., AFRIDI H. I., KANDHRO G. A., SARFRAZ R. A., JAMAL M. K., SHAH A.Q. Evaluation of arsenic and other physico-chemical parameters of surface and groundwater of Jamshoro, Pakistan. J. Hazard. Mater. 166, 662, 2009.

16. ARAIN M. B., KAZI T. G., BAIG J. A., JAMALI M. K., AFRIDI H. I., SHAH A. Q. S., ARFRAZ R. A. Determination of arsenic levels in lake water, sediment, and foodstuff from selected area of Sindh, Pakistan: estimation of daily dietary intake. Food. Chem. Toxicol. 47, (1), 242, 2009.

17. WHO. Guidelines for drinking-water quality. Geneva: World Health Organization. 2008.

18. LIM M. S., YEO I. W., CLEMENT T. P., ROH Y., LEE K.K. Mathematical model for predicting microbial reduction and transport of arsenic in groundwater system. Water. Res. 41, (10), 2079, 2007. 
19. TAWFIK D. S., VIOLA R. E. Arsenate Replacing Phosphate: Alternative Life Chemistries and Ion Promiscuity. Biochemistry. 50, 1128, 2011.

20. WINSKI S. L., CARTER D. E. Arsenate toxicity in human erythrocytes: characterization of morphologic changes and determination of the mechanism of damage. J. Toxicol. Env. Heal. A. 53, (5), 345, 1998.

21. CARTER D. E., APOSHIAN H. V., GANDOLFI A. J. The metabolism of inorganic arsenic oxides, gallium arsenide, and arsine: a toxicochemical review. Toxicol. Appl. Pharm. 193, (3), 309, 2003.

22. RADABAUGH T. R., APOSHIAN H. V. Enzymatic reduction of arsenic compounds in mammalian systems: reduction of arsenate to arsenite by human liver arsenate reductase. Chem. Res. Toxicol. 13, (1), 26, 2000.

23. WARD MH., DEKOK TM., LEVALLOIS P., BRENDER J., GULIS G., NOLAN BT., VANDERSLICE J. Workgroup Report: Drinking-Water Nitrate and Health - Recent Findings and Research Needs. Environ. Health Persp. 113, $1607,2005$.

24. TRICKER A.R. N-nitroso Compounds and Man: Sources of Exposure, Endogenous Formation and Occurrence in Body Fluids. Eur. J. Cancer Prev. 6, 226, 1997.

25. ROCHA-AMADOR D., NAVARRO ME., CARRIZALES L., MORALES R., CALDERÓN J. Decreased Intelligence in Children and Exposure to Fluoride and Arsenic in Drinking Water. Cadernos de Saúde Pública, 23, (4), 579, 2007.

26. FAROOQ S., HASHMI I., QAZI I. A., QAISER S., RASHEED S. Monitoring of coliforms and chlorine residual in water distribution network of Rawalpindi, Pakistan. Environ. Monit. Assess. 140, (1-3), 339, 2008.

27. JEHANGIR M. Bacteriological contamination and upward trend in nitrate contents, observed in drinking water of Rawalpindi and Islamabad. Pakistan: The Network Consumer Protection in Pakistan. 2002.

28. SHAR A. H., KAZI Y., ZARDARI M., SOOMRO I. H. Enumeration of total and fecal coliform bacteria in drinking water of Khairpur Sindh. Pak. J. Med. Res., 47, 18, 2008.

29. MUMTAZ M. W., ADNAN A., MUKHTAR H., NAWAZ K., RAZAA., AHMAD Z. Estimation of bacteriological levels in surface water samples to evaluate their contamination profile. Environ. Monit. Assess. 172, (1-4), 581, 2011.

30. HUSSAIN M. U. S. H. T. A. Q., RASOOL S. A., KHAN M. T., WAJID A. B. D. U. L. Enterococci vs coliforms as a possible fecal contamination indicator: baseline data for Karachi. Pak. J. Pharm. Sci. 20, (2), 107, 2007.

31. PCRWR. National Water Quality Monitoring Programme. Water Quality Report 2003-2004. Islamabad, Pakistan: Pakistan Council for Research in Water Resources (PCRWR), 2005. available at: http://www.pcrwr.gov.pk/wq phase3_report/TOC.htm.

32. SHRESTHA B. Drinking water quality: future directions for UNICEF in Pakistan Consultancy Report 2 of 3, Water Quality, SWEET Project, UNICEF Pakistan, Islamabad. 2002.

33. ULLAH R., MALIK R. N., QADIR A. Assessment of groundwater contamination in an industrial city, Sialkot, Pakistan. Afr. J. Environ. Sci. Technol. 3, (12), 429, 2009.

34. NASRULLAH, NAZ R., BIBI H., IQBAL M., DURRANI M. I. Pollution load in industrial effluent and ground water of Gadoon Amazai Induatrial Estate (GAIE) Swabi, NWFP. Journal of Agricultural and Biological Science. 1, (3), 18, 2006.
35. FAROOQI A., MASUDA H., FIRDOUS N. Toxic Flouride and Arsenic Contaminated Ground Water in the Lahore and Kasur districts Punjab, Pakistan, and possible Contaminant Sources. Environ. Pollut. 145, (3), 839, 2007.

36. NICKSON R. T., MCARTHUR J. M., SHRESTHA B., KYAW-MYINT T.O., LOWRY D. Arsenic and other drinking water quality issues, Muzaffargarh District, Pakistan. Appl. Geochem. 20, (1), 55, 2005.

37. ARAIN M. B., KAZI T. G., JAMALI M. K., AFRIDI H. I., BAIG J. A., JALBANI N., SHAH A. Q. Evaluation of Physico-chemical Parameters of Manchar Lake Water and Their Comparison with Other Global Published Values. Pak. J. Anal. Environ. Chem, 9, (2), 101, 2008.

38. APHA. Standard Methods for the Examination of Water and Wastewater. $18^{\text {th }}$ edition. American Public Health Association, Washington, DC. 1992.

39. Guidelines for drinking-water quality, fourth edition World Health Organization, 2011.

40. U.S EPA. National Primary Drinking Water Regulations. United States Environmental Protection Agency EPA 816-F09-004, May 2009.

41. NSDWQ. Pakistan Environmental Protection Agency, Ministry of Environment, Government of Pakistan. National Standards for Drinking Water Quality. 2008.

42. SHAHID N., ANWAR S., QADIR A., ALI H., SUCHENTRUNK F., ARSHAD H. M. Accumulation of selected heavy metals in Lepus nigricollis from Pakistan. J. Basic. Appl. Sci. Res. 3, (11), 339, 2013.

43. KHAN K., LU Y., KHAN H., ZAKIR S., IHSANULLAH KHAN S., KHAN A.A., WEI L., WANG T. Health risks associated with heavy metals in the drinking water of Swat, northern Pakistan. J. Environ. Sci. 25, (10), 2003, 2013.

44. US EPA. Exposure Factors Handbook. United States Environmental Protection Agency, Washington, DC. EPA/600/R-09/052F. 2011.

45. JAN F. A., ISHAQ M., KHAN S., IHSANULLAH I., AHMAD I., SHAKIRULLAH M. A comparative study of human health risks via consumption of food crops grown on wastewater irrigated soil (Peshawar) and relatively clean water irrigated soil (lower Dir). J. Hazard. Mater. 179, (1), 612, 2010.

46. IRIS. U.S EPA International Risk Information System (IRIS) (www.epa.gov/iris). 2007.

47. MUHAMMAD S., TAHIR SHAH M., KHAN S. Arsenic health risk assessment in drinking water and source apportionment using multivariate statistical techniques in Kohistan region, northern Pakistan. Food and Chemical Toxicology, 48, (10), 2855, 2010.

48. HALIM M.A., MAJUNDER R.K., NESSA S.A., ODA K., HIROSHIRO K., SAHA B.B., HUSSAIN S.M., LATIF S.A., ISLAM M.A., JINNO K. Groundwater contamination with arsenic in Sherajdikhan, Bangladesh: geochemical and hydrological implications. Environ. Geol. 58, 73, 2009.

49. IARC. Working Group on the Evaluation of Carcinogenic Risks to Humans. "Some drinking-water disinfectants and contaminants, including arsenic." IARC monographs on the evaluation of carcinogenic risks to humans/World Health Organization, International Agency for Research on Cancer. 84, 1-477, 2004.

50. SCHUHMACHER-WOLZ U., DIETER H. H., KLEIN D., SCHNEIDER K. Oral Exposure to Inorganic Arsenic: Evaluation of Its Carcinogenic and Non-Carcinogenic Effects. Crit. Rev. Toxicol. 39, (4), 271, 2009.

51. ATSDR. Agency for Toxic Substances and Disease Registry. Arsenic Toxicity: Case Studies in Environmental Medicine, ATSDR, Atlanta. 2000. 
52. WHO/IPCS. Environmental health criteria 224, arsenic and arsenic compounds. $2^{\text {nd }}$ ed. Geneva: World Health Organization. 2001.

53. RAHMAN M., VAHTER M., SOHEL N., YUNUS M., WAHED M. A., STREATFIELD P. K., PERSSON L. A. Arsenic exposure and age-and sex-specific risk for skin lesions: a population-based case-referent study in Bangladesh. Environ. Health. Perspect. 114, 1847, 2006.

54. RAHMAN M., VAHTER M., WAHED M. A., SOHEL N., YUNUS M., STREATFIELD P. K., PERSSON L. A. Prevalence of arsenic exposure and skin lesions. A population based survey in Matlab, Bangladesh. J. Epidemiol. Community. Health. 60, (30), 242, 2006.

55. FATMI Z., AZAM L., AHMED F., KAZI A., GILL A. B., KADIR M. M., AHMED M., ARA N., JANJUA N. Z., PANHWAR S. A., TAHIR A., AHMED T., DIL A., HABAZ A., AHMED S. Health burden of skin lesions at low arsenic exposure through groundwater in Pakistan, is river the source?. Environ. Res. 109, (5), 575, 2009.

56. FLANAGAN S.V., JOHNSTON R.J, ZHENG Y. Health and economic impact of arsenic in Bangladesh: implications for mitigation strategy and practice. Bulletin of the World Health Organization. 2012 [In Press].

57. WELCH A.H., WESTJOHN D. B., HELSEL D. R., WANTY R. B. Arsenic in ground water of the United States: occurrence and geochemistry. Ground water. 38, (4), 589, 2000.

58. SCHREIBER M. E., SIMO J. A., FREIBERG P. G. Stratigraphic and geochemical controls on naturally occurring arsenic in groundwater, eastern Wisconsin, USA. Hydrogeol. J. 8, (2), 161, 2000.

59. MCARTHUR J. M., RAVENSCROFT P., SAFIULLAH S., THIRLWALL M. F. Arsenic in groundwater: testing pollu- tion mechanisms for aquifers in Bangladesh. Water. Resour. Res. 37, (1), 109, 2001.

60. RAVENSCROFT P., MCARTHUR J. M., HOQUE B. A. Geochemical and palaeo hydrological controls on pollution of groundwater by arsenic. Arsenic exposure and health effects. 4, 53, 2001.

61. ROBERTSON F. N. Arsenic in ground-water under oxidising conditions, south-west United States. Environ. Geochem. Health. 11, (3-4), 171, 1989.

62. POPOVIC A., DJORDJEVIC D., POLIC P. Trace and major element pollution originating from coal ash suspension and transport processes. Environ. Int. 26, (4), 251, 2001.

63. BHATTACHARYA P., MUKHERJEE A. B., JACKS G., NORDQVIST S. Metal contamination at a wood preservation site: characterization and experimental studies on remediation. Sci. Total. Environ. 290, (1), 165, 2002.

64. WANG S., MULLIGAN C. N. Occurrence of arsenic contamination in Canada: sources, behavior and distribution. Sci. Total. Environ. 366, (2), 701, 2006.

65. AHMAD S. R., KHAN M. S., KHAN A. Q., GHAZI S., ALI S. Sewage water intrusion in the groundwater of Lahore, its causes and protections. Pak. J. Nut. 11, (5), 484, 2012.

66. FRIEDMAN M. J. Establishing site-specific flushing velocities. Awwa Research Foundation and Kiwa NV. 2003.

67. EMDE K. M. E., SMITH D. W., FACEY R. Initial investigation of microbially influenced corrosion (MIC) in a low temperature water distribution system. Water Res, 26, (2), 169, 1992.

68. EMMANUEL E., PIERRE M.G., PERRODIN Y. Groundwater contamination by microbiological and chemical substances released from hospital wastewater and health risk assessment for drinking water consumers. Environ. Int. 35, 718, 2009. 